\title{
WIELOKULTUROWOŚĆ: LEKCJE PRZESZŁOŚCI
}

Review: Understanding Multiculturalism. The Habsburg Central European Experience, ed. Johannes Feichtinger, Gary B. Cohen, Berghahn, Oxford-New York, 2014 (Austrian and Habsburg Studies 17), pp. 246

\section{MULTICULTURALISM: LESSONS FROM THE PAST}

\begin{abstract}
While recently the concept of multiculturalism has been an object of strong criticism from the political side, the book under review takes another turn scrutinizing and historicizing it. Looking at Central Europe through the lenses of nonessentialism, postcolonialism or national indifference, multiple authors propose not only new ways of reading the history of the region, but also of establishing categories for the future research in historical cultural studies.
\end{abstract}

Key words: Central Europe; multiculturalism; postcolonial theory

Recenzja: Understanding Multiculturalism. The Habsburg Central European Experience, red. Johannes Feichtinger, Gary B. Cohen, Berghahn, Oxford-New York, 2014 (Austrian and Habsburg Studies 17), ss. 246.

\section{Streszczenie}

Podczas gdy koncept wielokulturowości był w ostatnim czasie obiektem mocnej krytyki, szczególnie ze strony polityki, recenzowana książka obiera inną pozycję, analizując i historyzując go. Spoglądając na Europe Środkową z użyciem nieesecjalizujących czy postkolonialnych koncepcji, autorzy proponują nie tylko nowe sposoby odczytania historii regionu, lecz także nowe kategorie dla przyszłych badań historii kulturowej.

Stowa kluczowe: Europa Środkowa; wielokulturowość; teoria postkolonialna

JAN SURMAN Herder-Institut, Marburg, Deutschland E-mail: jan.surman@herder-institut.de This work was supported by the author's own resources. No competing interests have been declared.

This is an Open Access article distributed under the terms of the Creative Commons Attribution 3.0 PL License (creativecommons.org/licenses/by/3.0/pl/), which permits redistribution, commercial and non-commercial, provided that the article is properly cited. (C) The Author(s) 2016.

Publisher: Institute of Slavic Studies, Polish Academy of Sciences [Wydawca: Instytut Slawistyki PAN] 


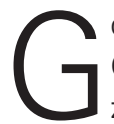
dy w 2006 roku w Minneapolis kształtowała się grupa „Multiculturalism: The Central European Experience and Its Impact on Identity Formation in a Globalized World", której badania opublikowane są w omawianym tutaj, opublikowanym w 2014 roku tomie, pytania o wielokulturowość zaczynały interesować zarówno naukowców jak i opinię publiczną. Gdy piszę tę recenzję, w Niemczech płoną ośrodki dla uchodźców, węgierski rząd buduje mur mający ograniczyć przypływ imigrantów z Serbii, a hołdująca tradycji wielokulturowej Rzeczpospolitej Polska niedawno zgodziła się przyjąć w następnych latach mniej imigrantów, niż znalazło miejsce na Tytanicu. Nawet jeżeli społeczeństwo obywatelskie w każdym z tych przypadków jest nieporównywalnie bardziej otwarte niż przytoczone tutaj prawicowe fobie, pytanie o sposoby radzenia sobie w wielojęzycznych, wielokulturowych sytuacjach, stało się jednym z głównych, o ile nie nawet gtównym pytaniem polityki europejskiej. Pytanie, które we wstępie zadają edytorzy, wiedeński historyk i kulturolog Johannes Feichtinger i Gary Cohen, dyrektor Centrum Studiów Austriackich Uniwersytetu w Minneapolis, jakie wyciągnąć można lekcje z przeszłości i teraźniejszości (post-)habsburskiej Europy Środkowej, wydaje się więc bardziej niż aktualne. Na niewiele ponad 200 stronach teoretycznych analiz i przykładów autorzy podejmują tutaj zadanie niełatwe - jak w okresie kryzysu wielokulturowości pisać o niej jako modelu przyszłości. Odpowiedź to zastąpienie wielokulturowości plurikulturowością, podkreślającą potrzebę akceptacji różnic ${ }^{1}$, lecz także nieesencjalizujące pojęcie kultury jako komunikacji a nie utopijnej pierwotnej wspólnoty.

Pierwsze trzy artykuły zadają pytanie o teoretyczne ugruntowanie tej teorii. Anil Bhatti z New Deli, odnosząc się do kolonialnych i postkolonialnych Indii, oraz Monarchii Habsburskiej, zgłębia możliwości wielojęzycznej i wielokulturowej egzystencji współczesnego globalnego społeczeństwa. Michael Rössner (Monachium/Wiedeń) koncentruje się na rozważaniach o heterogeniczności kulturowej w Ameryce Łacińskiej. Pieter Judson (Florencja) dyskutuje natomiast o nacjonalizacji wiejskich obszarów Monarchii Habsburskiej.

Esej Bhattiego to niezwykle aktualna analiza znaczenia i genezy terminu podobieństwa (similarity/Ähnlichkeit) które powinno zastąpić tożsamość (w znaczeniu sameness/ Gleichaltrigkeit), żeby umożliwić funkcjonowanie nowoczesnych, coraz bardziej kulturowo zróżnicowanych społeczeństw (por. też np. Bhatti, 2014). Jak pokazuje Bhatti, zarówno w Monarchii Habsburskiej jak i w kolonialnych Indiach rozwinięte zostały koncepcje podkreślające właśnie te nieesencjalizujące właściwości kultury czy języka. Bhatti rozpoczyna swoją analizę, kontrastując podejścia do wielokulturowości Johanna Gottfrieda Herdera i Goethego - podczas gdy ten pierwszy opowiadał się za różnorodnością oddzielnych i homogenicznych narodów (Völker), Goethe nie tylko wypowiadał się przychylniej o nieodzownie połączonych poprzez kontakty transnarodowej kulturze - Weltliteratur ale widział ją jako wpływającą pozytywnie na pojedyncze narody. Poszukując wyzwolenia z kolonializmu, indyjski pisarz Rabindranath Tagore widział przyszłość nie w nacjonalizmie, lecz w akceptacji różnic kulturowych i uniwersalizmie (Feichtinger \& Cohen, 2014, s. 27); w odróżnieniu od habsburskich teoretyków (np. Otto Bauera i Karla Rennera) nie esencjalizował jednak kultur narodowych jako pierwotnych jednostek gwarantujących społeczną solidarność. Tagore podkreślał także komunikacyjną funkcję języka ponad charakterystycznym dla teorii jednojęzykowości symbolicznymi funkcjami. Właściwa Indiom wielojęzyczność (w formie znajomości wielu języków, nawet jeżeli nie „pełnej” i moż-

Jak pisze Moritz Csáky: „Plurikulturowość nie tylko akceptuje zróżnicowanie, implikuje ona jednocześnie intelektualne postępowanie uznania różnic i obchodzenia się z tą realną różnorodnością. Tego konceptu nie można więc uznać za tożsamy z wielokulturowością (Multikulturalität), która utrzymuje krzyżowanie się kulturowych różnic poprzez harmoniczne współżycie i poprzez to eliminację sprzeczności" (Csáky, 2011). 
liwości komunikacji w nich) była ideałem także dla habsburskiego orientalisty Josepha Hammer-Purgstalla - jak zauważa Bhatti, jest ona inna od obecnie obowiązującego modelu Unii Europejskiej, uprzywilejowującego jeden język (angielski). Te (i inne omówione) podejścia mogą według Bhattiego pomóc w przejściu od wielokulturowości do bardziej „płynnych, komunikacyjnie otwartych warunków plurikulturowości” (s. 40), dla których dewizą nie będzie „unity in diversity", lecz "similarity in diversity”.

Konstatując porażkę na polu kulturowym europejskiego modelu wielonarodowej unii, Michael Rössner przywołuje dyskusje o mestizaje w Ameryce Łacińskiej. Według niego to właśnie tereny transatlantyckie były uprzywilejowanym terenem dla pojawienia się "europejskiego ducha”, gdyż "nie dało się przypisać indywidualnych europejskich kultur narodowych do lokalnych populacji, mimo że były one przede wszystkim europejskiego pochodzenia" (s. 49). Tak na przykład eseista i przyszły prezydent Argentyny Dominigo Faustino Sarmiento już w 1845 roku miał „europejskość” przed oczami, kontrastując ją z amerykańską dzikością i hiszpańską średniowieczną brutalnością. Podczas gdy w XIX wieku europejskość łączona była z kulturą i cywilizacją, w XX wieku mestizaje, połączenie lokalnej i europejskiej kultury, stało się główną figurą dyskursu. Prowadziło to także u niektórych autorów, na przykład José Valoscencelosa w latach 1920., do opisania mestizaje jako „nadludzkiej zmieszanej rasy” (s. 52), prowadząc więc do podobnej jak w Europie biologizacji. Jednak od lat 70. pojawia się coraz powszechniej koncept tożsamości jako „jarmarków negocjacji pomiędzy różnymi nakładającymi się na siebie i czasami splatanymi społecznymi, etnicznymi, religijnymi czy kulturowymi grupami, przy braku linearności w czasie i przestrzeni" (s. 52), wyprzedzając tym teorię hybrydyczności Homiego Bhabhy. To właśnie akceptacja rhizomatycznej piazzy, której ideały Rössner znajduje także w rozważaniach habsburskich autorów (Hugo von Hoffmansthal, Robert Musil etc.), jest według Rössnera konieczna dla wytworzenia integracyjnej i inkluzyjnej europejskości.

Pieter Judson spogląda na pojawienie się i szczególnie terytorializację narodu w Monarchii Habsburgów, które doprowadziły do ideałów jednojęzykowych regionów, prowincji i państw. Jak zauważa, historycy zbyt często biorą nacjonalistyczną agitację, szczególnie w literaturze, lecz także w pracach historycznych czy statystycznych, za odzwierciedlenie historycznej rzeczywistości, podczas gdy XIX wiek to historia dość agresywnego i często konfliktowego procesu „unaradawiania” wsi. Linie konfliktu nie biegły, jak można by przypuszczać, tylko pomiędzy przedstawicielami różnych „narodów”, lecz pomiędzy aktywistami a ludem, któremu ci pierwsi narzucali nowe formy społecznej interakcji, przekreślając poprzednią wielojęzyczność. Judson posiłkuje się tutaj szczególnie pracami Rogersa Brubakera oraz Jeremego Kinga (2002) i Tary Zahry (2008). Jak zauważa Judson, proces unaradawiania to także terytorializacja, poprzez cenzus i mapy, lecz także metafory jak granica językowa. Co ważne, nawet tutaj widać niepraktyczność nacjonalistycznych teorii: podczas gdy narodowi aktywiści pisali o narodowości jako czymś wrodzonym, to sięgając do coraz nowych grup, w dość oczywisty sposób praktykowali "konwersję" i tym samym kulturową wersję narodowości (Feichtinger \& Cohen, 2014, s. 76).

Kolejne trzy artykuły zebrane w sekcji "The Dynamics of Multicultural Societies, Politics, and the State" koncentrują się na studiach przypadku, Hucułach (Patrice Dabrowski), Istrii (Pamela Ballinger) i Austrii (John Michael). Dabrowski opisuje ciekawy przypadek międzywojennej Polski, która w większości badań zachodnich uważana jest za państwo unaradawiające (nationalising state) a nie wielokulturowe. Jak podkreśla jednak na przykładzie piłsudczyków, wojewody wołyńskiego Henryka Józewskiego i działacza państwowego Tadeusza Hołówki, idee wielokulturowości jako przyszłości państwa przynajmniej 
do 1926 roku były dość popularne, nawet jeżeli później to narodowościowa wizja Polski a'la Dmowski stała się dominującą. Dabrowski pokazuje konkretne działania na przykładzie Huculszczyzny i krajoznawczej organizacji Towarzystwa Przyjaciół Huculszczyzny. Odkrycie Karpat szło ręka w rękę z romantyczną wizją nienarodowych, "czystych" Hucułów (np. u Stanisława Vinzenza [Станіслав Вінценз]), do których zachowania utworzono nawet Sekcję Obrony Swojszczyzny czy Muzeum Huculskie w Żabiem - Dabrowski używa pojęcia "Słowiańskiej Atlantydy" (s. 96). W ten sposób Huculszczyzna nie była Polską B, lecz raczej „miała wiele do zaoferowania tym w centrum: kulturową odmienność i egzotykę, wzmacniający klimat i możliwości korzystania z nich" (s. 92). Jak podkreśla, była to często wizja medialna, specjalnie dopasowywana do przekazu, zarówno pod względem manipulowania historią, jak i już zainfekowanej nowoczesnością rzeczywistości. Nie zmienia to jednak faktu, że nawet w „unaradawiającym” państwie, nie zawsze z powodów zachowania kulturowego zróżnicowania (tutaj chodziło także o immunizację Hucułów przeciwko ukraińskiemu nacjonalizmowi), wielokulturowość mogła być ważnym ogniwem kształtowania lokalnej polityki.

Po modelu peryferii II Rzeczypospolitej Ballinger opisuje podobnie niecentralną Istrię. Podkreśla tutaj wielojęzyczną tożsamość Istryjczyków, która opierała się zarówno etnizacji w czasach Monarchii Habsburskiej, jak i Jugosławii po 1989 roku, charakteryzowanym już przez obecność granic, zarówno lądowych jak i morskich, ważnych dla mieszkańców portowych miast z powodu limitów połowu. Jak podkreśla, poprzez zachowanie wielojęzykowych tradycji oraz opieranie się najpierw na weneckim micie pochodzenia, teraz coraz bardziej na micie kontaktowej przestrzeni Adriatyku/Morza Śródziemnego, do tej pory udało się zachować wspólną tożsamość pomimo bycia podzielonymi granicami i istniejących sporów gospodarczych. Bellinger pozostaje jednak sceptyczna, czy na istryjskim modelu oprzeć można przyszłe modele: podczas gdy Istryjczycy są wielokulturowi, to ich otwartość na włączanie nowych przybyszy do społeczności jest dość limitowana. Jest on już "melted pot” (s. 116), używając słów jednej z badaczek regionu.

Jak pokazuje John Michael, także postimperialna Austria była otwarta dla ludzi różnych języków, którzy po rozpadzie monarchii wybrali obywatelstwo austriackie. Podczas gdy Wiedeń starał się ich integrować i mieli oni tam np. dość popularne partie, inne miasta raczej ich wyłączały. Wyraźnie oddzielano także autochtonicznych obcych (Słoweńców, Czechów itd.) od allochtonicznych, jak (nowo imigrujący) Żydzi czy Romowie. Także ta różnorodność konfrontowana była z problemami - wprowadzeniem kategorii rasy do cenzusu, manipulowania jego datą dla zminimalizowana liczby nie-Niemców, a szczególnie z nazizmem i jego ideologiami (które nota bene, nie tylko trafiły w Austrii na podatny grunt lecz tutaj się także rozwijały). Podczas gdy w czasie II wojny światowej w Austrii przebywało około miliona pracowników przymusowych, po 1945 roku byli to głównie przesiedleńcy, którzy, podobnie jak emigranci polityczni w latach komunizmu, w większości opuścili kraj, migrując dalej². Także pracownicy gościnni (Gastarbeiter), którzy szczególnie z Jugosławii i Turcji, mieli, według przewidywań rządu, pozostawać w kraju tylko kilka lat. Zmiany po rozpadzie ZSRR i wojna w Jugosławii doprowadziły do wzrostu liczby imigrantów do 10\% populacji Austrii (s. 137). Jak podkreśla Michael, wielokulturowość i różnorodność nie była jednak widziana jako podstawa budowania tożsamości nowoczesnej Austrii, dopiero ostatnie dziesięciolecia i Unia Europejska doprowadziły do ograniczonej dyskusji. Mimo że część społeczeństwa nazwać można pluralistycznym, silne są także

2 Na przykład po stanie wojennym z 120.000-150.000 Polaków i Polek przybyłych do Austrii, 33.000 aplikowato o azyl polityczny (s. 133). Michael nie podaje jednak, ile osób go dostało. 
tendencje prawicowe i eksluzywistyczne, szczególnie w niezmiernie wpływowej prasie brukowej. Według ostatnich badań „wielokulturowość” ma pozytywne konotacje tylko dla około 15\% Austriaków, a pojęcie „obcokrajowiec” dla 7\%, zaś główne pojęcia z którymi identyfikują się mieszkańcy, to pewność (Sicherheit) i porządek (Ordnung) (s. 148).

Dwa kolejne artykuły koncentrują się na peryferyjnych praktykach pluralizmu. Oto Luthar, dyrektor Instytutu Studiów nad Pamięcią i Kulturą Stoweńskiej Akademii Nauki (Inštitut za kulturne in spominske študije ZRC SAZU), opisuje, w jaki sposób wielokulturowość funkcjonowała w Prekmurje, teraz w Słowenii. Na przykładach książki kucharskiej Mariji Hujs oraz dziennika oficera Jozsefa Doncsecza pokazuje, że piszący używali wielu języków do opisania napotkanej rzeczywistości. Doncsecz na przykład używał niemieckiego do opisania oficjalnych spraw, słoweńskiego do opisywania relacji ze swą ukochaną Etelką, węgierskiego do fantazji seksualnych i lokalnej mieszanki chorwacko-serbsko-bośniackiej dla reprodukcji śpiewów tawernianych. Jak podkreśla Luthar, w takich sytuacjach nie tylko koncept "mother tongue" traci sens i ujawnia się znaczenie języka jako socjolektu, ale także pokazuje się inny model kultury. Autor cytuje tutaj badania Bernarda Lory'ego o macedońskim miasteczku Bitola (Lory, 2011), w których francuski badacz pisał o mieście, które ma "jedną, wielojęzykową i wielce eklektyczną kulturę" (Feichtinger \& Cohen, 2014, s. 167). Ta kultura może według Luthara być odpowiedzią na zadane w 2006 roku przez Ernsta Bruckmüllera pytanie, czy istniało społeczeństwo habsburskie (Bruckmüller, 2006), nawet jeżeli nie da się generalizować na całą Monarchię. Germanista na Uniwersytecie laşi, Andrei Corbea-Hoisie, analizuje inną peryferię, Czerniowce, w których, jak pisze, sielska kultura skonfrontowana została w czasach habsburskich z miejskością, wraz z jej charakterystykami jak pojawiania się "obcego” czy przejęcia władzy nad lokalnymi mieszkańcami przez nowo przybyłych. Jak pisze, u autorów takich jak Gregor von Rezzori czy Aaron Appelfeld pojawia się motyw mamki, która łączy te kultury, nawet jeżeli jest to promesse du bonheur idyllicznej wielokulturowości, które nigdy nie może zostać spełniony (s. 183).

Kończy książkę artykuł będący propozycją zgłoszoną przez wiedeńskiego kulturologa Moritza Csáky'ego, jak opisywać kulturę w Europie Środkowej nie z punktu widzenia narodowych teleologii, lecz jako sferę komunikacji. Positkując się definicjami Clifforda Geertza, Malinowskiego czy Stephena Greenblatta, autor proponuje następującą operacjonalizację:

Kultura powinna zostać zdefiniowana jako repertuar elementów, znaków, symboli czy kodów za pomocą których indywidua komunikują się ze sobą. Kultura jest przestrzenią komunikacji, w której poprzez ustalenie i dyslokacje znaków konstytuują się światy życia (lifewords) i rekonfigurowane zostają relacje władzy. Kultura jest przestrzenią komunikacji z przenikalnymi granicami, dodawane są coraz to nowe elementy, a inne pozbawiane są znaczeń, są kodowane na nowo lub odrzucane. Kultura jest tkaniną wątków (orienting thread), językowych jak i mimetycznych form zachowania i wzorów zachowania; po krótce, znaczeń poprzez które jednostki jak i grupy społeczne usiłują manewrować poprzez wszechogarniającą przestrzeń społeczną (s. 195).

Jak podkreśla Csáky, ta definicja pozwala na dynamizowanie kultury, bez odrzucania specyficznych kulturalnych konfiguracji różnic; jest ona inkluzyjna językowo i społecznie, pozwalając jednostkom na branie udziału w różnych przestrzeniach komunikacji i nie tworzy iluzji stałych granic; na koniec, nie odrzuca wartości ekonomicznych (bargaining) czy kwestii władzy (ss. 196-200). To podejście Csáky ilustruje miejskimi przestrzeniami ok. 1900 roku czy także wzmiankami o autorach, których nie da się zrozumieć poprzez tradycyjne pojęcie kultury, jak Marko Czeremszyna czy Tadeusz Rittner. 
Oczywistym jest, że podejścia te, wewnętrznie pluralistyczne pomimo wielu cech wspólnych, nie dają gotowych odpowiedzi i instrukcji, stwarzają jednak wiele nowych idei do koncypowania zarówno historycznych badań jak i polityki: na przykład komunikacyjna definicja kultury Csáky'ego czy jej opis u Bhattiego jako rhizom i palimpsest (ss. 36-38). W tym sensie udaje się odejść od "metodologicznego nacjonalizmu” i esencjalizowania kultury. Tom ten, w przeciwieństwie do wielu posthabsburskich apologetów rzekomo utraconej wielokulturowości nie romantyzuje także plurikulturalizmu, chociaż tylko Ballinger tematyzuje problemy Istrii. Pozostaje jednak kilka pytań, i w tym zakresie tom nie spełnia oczekiwań. Po pierwsze, tylko Luthar spogląda na aktorów podporządkowanych i ich codzienność, co stoi w przeciwieństwie do teoretycznych ram proponowanych, na przykład, przez Judsona, który proponuje przejrzeć przez narrację aktywistów - tutaj np. u Dabrowski mamy analizę aktywistów wielokulturowości, a w innych przypadkach, teoretyków. Powstaje tutaj także pytanie: jak dalece państwa XIX i XX wieku były zainteresowane krzewieniem wielokulturowości - bolesny jest tutaj brak artykułu o Czechosłowacji, najbardziej chyba wielokulturowym państwie lat 20. XX wieku, które otwarcie nawiązywało do tradycji habsburskich. W ogóle zaskakuje w tomie opuszczenie kwestii władzy i siły w procesie formowania tak ruchów narodowych jak i wielokulturowości. Największe zastrzeżenie to jednak brak analizy innych czołowych tożsamości niż tylko lokalne na przykład zawodowej czy religijnej - które w podobny sposób transcendują tradycyjne, związane z językiem, pojęcie kultury i na które uwage zwracali już przywoływani przez autorów socjologowie Pierre Bourdieu czy Norbert Elias. Bez wątpienia jednak tom jest ciekawym głosem w dyskusji o kształcie nowoczesnej kultury i jej historycznej analizie, a proponowane przez autorów teoretyczne podejścia będą podłożem do kolejnych dyskusji, nie tylko w historiografii.

\section{BIBLIOGRAFIA}

Bhatti, A. (2014). Cultural similarity does not mean that we wear the same shirts: Similarity and difference in culture and cultural theory: An interview with Anil Bhatti. A Journal of Literary Studies and Linguistics, 4(2), 13-23.

Bruckmüller, E. (2006). Was there a 'Habsburg society' in Austria-Hungary? Austrian History Yearbook, 37, 1-16.

Csáky, M. (2011). Zentraleuropa - ein komplexer Kommunikationsraum: Festrede an der Ludwig-Maximilians-Universität München. Pobrano 23 sierpnia 2014, z www.schroubek-fonds.volkskunde.uni-muenchen.de/foerderprogramme/preise/preis_2011/csaky/ index.html

Feichtinger, J., \& Cohen, G. B. (Red.). (2014). Understanding multiculturalism: The Habsburg Central European experience. New York: Berghahn.

King, J. (2002). Budweisers into Czechs and Germans: A local history of Bohemian politics, 1848-1948. Princeton: Princeton University Press.

Lory, B. (2011). La ville balkanissime: Bitola 1800-1918. Istanbul: Éditions Isis.

Zahra, T. (2008). Kidnapped souls: National indifference and the battle for children in the Bohemian Lands, 1900-1948. Ithaca: Cornell University Press. 